\title{
Local Government Internal Audit
}

\section{Compliance}

\author{
Greg Jones $^{1}$ and Claire Beattie ${ }^{2}$
}

\begin{abstract}
Local government councils (LGC) rely on a number of funding sources including state and federal governments as well as their community constituents to enable them to provide a range of public services. Given the constraints on these funding sources councils need to have in place a range of strategies and policies capable of providing good governance and must appropriately discharge their financial accountabilities. To assist LGC with meeting their governance and accountability obligations they often seek guidance from their key stakeholders. For example, in the Australian State of New South Wales (NSW), the Office of Local Government has developed a set of guidelines, the Internal Audit Guidelines. In 2010 the NSW Office of Local Government issued revised guidelines emphasising that an internal audit committee is an essential component of good governance. In addition, the guidelines explained that to improve the governance and accountability of the councils, these committees should be composed of a majority of independent members. To maintain committee independence the guidelines indicated that the Mayor should not be a member of the committee. However these are only guidelines, not legislated requirements and as such compliance with the guidelines, before they were revised, has been demonstrated to be quite low (Jones \& Bowrey 2013). This study, based on a review of NSW Local Government Councils’2012/2013 reports, including Annual Reports and associated disclosures, assesses the level of compliance with the 2010 revised guidelines, specifically in relation to internal audit committees, to determine if the guidelines are effective in improving local government council governance.
\end{abstract}

JEL Classification: M42, M48, H71, H83.

Keywords: Accountability, Audit, councils, governance, internal audit, local government.

\footnotetext{
${ }^{1}$ University of Southern Queensland, gregory.jones@usq.edu.au

${ }^{2}$ University of Southern Queensland, claire.beattie@usq.edu.au
} 


\section{Introduction}

Local councils in Australia were initially established to provide basic public services such as road maintenance, waste removal and water supply to their communities. Over time the councils have evolved and are now responsible for providing an increasingly wider range of community services including aged and health care. Local councils have limited capacity to generate revenue and in order to be able to provide an ever increasing range of services they rely on funds generated through rates as well as grants from both state and federal governments. As trustees of a large portion of public assets and public funds councils are accountable for their actions to the community and to the governments who fund their activities. One key governance mechanism implemented to increase the accountability of councils is the provision of an internal audit function, with an independent audit committee. Guidelines for the establishment of the internal audit committee within councils were issued in 2010 (Department of Local Government (DLG) 2010b) and prior research (Jones \& Bowrey 2013) demonstrated that initially there was low level of compliance by councils with these guidelines.

This paper explores the subsequent compliance with these guidelines and provides a review of the recommendations from the Local Government Review Panel (Sansom, Munro \& Inglis 2013) on how to enhance accountability and governance with local councils.

\section{Local Council Background}

Local government in Australia was first established in the early 1800s with the country being divided into counties and parishes along the lines of the British model. However due to the fact that the sparsely populated new continent was not equivalent to the densely packed villages of England, local government initially did not work very well (NSWEdu 2002, NSWGov). After Federation in 1901, legislation was introduced by the various State Governments to consolidate the differing forms of local Government which had developed. It was at this time that Australian Local Councils were conceived "as a tool with which to provide basic property services” (Warburton \& Baker 2005, p. 62) to the community living within the local area. Similarly to the federal model, local governments in NSW were initially established by the NSW State Government as a mechanism for enabling local communities to provide their own local services. This also reduced state government duties by delegating them to the local authorities. From the time of the first settlement of NSW the Governor had complete authority over all governmental responsibilities, including local government. Subordinate to the Governor were a number of military commanders or civil magistrates who were charged with carrying out the governmental responsibilities. As the early colonial government was unable to provide adequate services to all the local areas, due to a lack of available funds and resources, the opportunity arose for the creation of municipal institutions to carry out some of these duties (NSWEdu 2002).

The Australian political arena operates under a government system with three distinct levels, consisting of federal (Commonwealth) government, state government and local 
government (Boon, Crowe, McKinnon \& Ross 2005). The federal government oversees a federation consisting of six states and two territories which have been granted authority to operate under the Commonwealth Constitution Act 1900 (Burritt \& Welch 1997). There are however a number of inequities between federal and state governments which are principally due to their differing capacities to raise revenue and therefore finance their expenditure commitments (Stilwell \& Troy 2000). The federal government is able to implement and control many expenditure policies by virtue of controlling the bulk of tax revenues granted under the Commonwealth Constitution Act (1900), thereby providing the federal government with the power and capacity to exercise a large amount of control over both state and local government expenditure. The federal government collects approximately $76 \%$ of the nation's tax revenue, the states $20 \%$ and Local Councils $4 \%$, which demonstrates the imbalance of income taxing powers (Stilwell \& Troy 2000, p. 115).

Local councils manage public monies and assets (NSW Trustees Act 1925) and accordingly they have a fiduciary responsibility to protect these assets as well as to manage those funds for the benefit of stakeholders. However as the federal and state governments possess most of the revenue raising powers local governments are heavily reliant on both for funding via operating and capital grants. Table 1 presents the total value of grants provided to NSW local government councils for the financial years 2011/12 and 2012/13.

Table 1 Total Grant Values

\begin{tabular}{|l|l|l|l|}
\hline \multicolumn{2}{|l|}{ Operating Grants (000's) } & \multicolumn{2}{l|}{ Capital Grants (000's) } \\
\hline 2013 & 2012 & 2013 & 2012 \\
\hline $1,550,000$ & $1,690,000$ & $1,430,000$ & $1,220,000$ \\
\hline
\end{tabular}

While the amounts in Table 1 indicate the amount of funding, the extent of reliance on those funds is highlighted in the Table 2. This compares the total operating profit of these councils when the operating grants are excluded. This shows that without grants from state and federal governments NSW councils are operating at substantial losses.

Table 2 Comparison of Operating Grants

\begin{tabular}{|l|l|l|l|}
\hline \multicolumn{2}{|l|}{ Total Operating profit \$000’s } & \multicolumn{2}{l|}{ Operating Profit excluding operating } \\
grants
\end{tabular}

Table 2 also demonstrates the level of publicly funded grants given to NSW councils. However, there has only ever been "low levels of accountability and very little performance measurement taking place” (Kloot 1999, p. 571). This reliance on subsidisation from the state government has contributed to the local councils being perceived as inefficient, and unable to manage the commercial elements of their operations (Barrett 2002). Proposals have been made that local councils should adopt a more business style approach to the management of the local government sector (Hood \& Peters 2004; Modell 2005; Skalen 2004; Worthington \& Dollery 
2002). Community concerns, which have been continually raised, have encompassed disquiet about the quality and comparability of public sector external reports, while also raising questions about both the efficiency, and the effectiveness of public sector management (Corporations Act 2001; Barton 1999; Hoque 2004; 2005). Additionally, one of the major concerns is that local governments have a high level of trust placed in them trusted with administering public funds, yet are seen to not be appropriately accountable for the funds under their management.

Consequently, the minimal levels of accountability which local councils have been demonstrating have resulted in demands for additional information on how governments manage and spend public funds (Kent 2003, p. 11). By the late 1970s due to the absence of specific standards for the public sector, the Commonwealth and State Auditors-Generals began to apply private sector standards to the public sector (Chua \& Sinclair 1994, p. 690). However, the accounting profession was not unanimous on the applicability of private sector standards being applied to public sector financial reports (Chua \& Sinclair 1994, p. 689) and suggested that there was not a "one size fits all” standard solution when comparing public and private entities. There have been several authors advocating that private sector practices and standards may be inappropriate for use within public-sector organisations (Barton 2005; Carnegie 2005; Carnegie \& West 2005).

\section{Governance and Accountability}

There are a variety of definitions of what good corporate governance entails. In Australia, while technically the system of corporate law is state based, in practice the primary legislation is the Corporations Act 2001, as the states all provide reference to the Federal Act within their own legislation (Hill 2010, p. 1). In recent times the commonwealth government has increased the focus on corporate governance (Bowrey 2008) as a means of increasing assurance and demonstrating adequate oversight of government bodies. From the perspective of the Commonwealth, corporate governance refers to "the processes by which organisations are directed, controlled and held to account. It encompasses attributes authority, accountability, stewardship, leadership, direction and control exercised in the organisation" (Australian National Audit Office (ANAO) 2003a, p. 6).

While the attention of corporate governance has been primarily on private sector organisations, it is equally important for public sector organisations to have strong corporate governance structures. Public bodies are responsible for the management and administration of public funds and are therefore expected to have good corporate governance systems in place (ANAO 2003a; Australian Public Service Ccommission (APSC) 2005; 2007). Edwards (2002) acknowledged that the corporate governance structures in both the public and private sectors have areas of commonality particularly in relation to performance and the roles and responsibilities of their governing boards and executive officers. This has led to a significant push for the public sector to adopt private sector corporate governance processes and structures. In the public sector the increased focus on performance and responsibilities is 
consistent with the move to "new managerialism" in the public sector (Jackson \& Lapsley 2003, p. 360) and the perceived need of the "public sector to improve its efficiency, effectiveness and accountability” (Barton 2005, p. 138; Guthrie 1998, p. 2).

Similarly, Uhrig (2003, p. 2) described corporate governance as "the power of those in control of the strategy and direction of an entity ... taking into account risk and the environment in which it is operating”. Barrett (2002, p. 8) proposed that the generally accepted meaning of corporate governance encompasses "how an organisation is managed, its corporate and other structures, its culture, its policies and strategies, and the ways in which it deals with its various stakeholders”. Likewise, Edwards (2002, p. 51-52) described governance as "dealing with all forms of the organisational relationships", and that good governance is able to "assist performance, provide accountability, transparency, participation and efficiency". Edwards (2002) also highlighted that the introduction of private sector practices into the public sector has created the assumption that the corporate (private) form of governance can be readily adapted to the public sector. The focus in recent times on corporate governance has been mainly on the impact of poor corporate governance, which has led to the collapse of a number of organisations (Allan 2006; Mak, Deo \& Cooper 2005; Parker 2005). These events have led to increased interest in "regulatory and other responses to improving corporate governance in the private sector" (ANAO 2003b, p.6).

While the emphasis of public sector reforms has been on the financial and budgetary measures for financial accountability, the performance of both programs and people are increasingly being measured. The expanding regulation of local councils has continued to increase the need for disclosure in a wide range of areas so that the actions of local councils can be scrutinised and allow them to be held to account for those actions (Gray 2001). These regulations and reliance on funding from state and federal governments impose duties on local councils to be accountable and provide reports and information to meet both the regulatory requirements of state and federal governments, and to address the needs of a variety of other stakeholders. Accountability is seen as an essential component of good management and practice, particularly as local councils have the responsibility and duty of managing public money. This has been demonstrated by the requirement of the NSW Trustees Act 1925 which highlighted that local councils, as managers of public funds, have a fiduciary responsibility to both protect public money and assets, and to ensure that they manage those funds for the benefit of all their stakeholders (NSW Trustees Act 1925).

Much like corporate governance, accountability is a broad concept to with a variety of understandings (Bovens 2007b; Carnegie 2005; Carnegie \& West 2005; Trippett \& Kluvers 2010) with a common consensus being that in order to be accountable; an essential requirement ought to be that one party must be obliged to provide a full account of events to another party, with an obligation to both "explain and justify his or her conduct" (Bovens 2007a, p. 447). Within the local council context, councils are required to provide a variety of reports and accounts to the State government (via the NSW Office of Local Government), yet does that make them accountable? The providing of information may be an essential component of accountability (Australian Securities and Investments Commission (ASIC) 
2001; Funnell 1998, 2003; Funnell, Jupe \& Andrew 2009) however the availability of additional information does not automatically lead to greater accountability (Broadbent \& Laughlin 2003). Barton (2005) argues that genuine accountability requires openness, transparency, that there is someone to whom you are required to report, and that there are consequences for inappropriate actions.

One factor highlighted by Brown (2011), was that insufficient controls, such as failure to have an internal audit function, has meant that councillors have had to rely on reports provided from the general manager or other council staff. This has raised concerns about governance weakness within the Local Councils, as there is no check or mechanism in place to confirm the validity of information and reports provided. Gold (2008, p. 51) has proposed that Local Council governance was inadequate, and that stakeholders are being exposed to "imprudent investment decisions and economically sub-optimal outcomes". Even before the Global Financial Crisis and the subsequent credit market crash was apparent, the NSW Department of Local Government was providing information to local councils reminding them of their fiduciary duties and responsibilities in respect to financial investments. This communication highlighted to local councils that their responsibility was to ensure that investments were made in accordance with the Act with the "onus for investments ... to be on preservation of capital rather than the rate of return” (DLG 2006, p. 36).

\section{Internal Audit Function and Audit Committees}

Internal auditing is used as a tool to monitor and improve the effectiveness of internal controls within organisations. The primary concerns of internal auditors are to identify areas of risk and determine methods of controlling and minimising those risks. Sound and reliable internal auditing provides a strong mechanism to contribute to the governance and accountability requirements of local councils (DLG 2008) through an independent internal audit committee which in turn contributes to providing objective assurance that the accountability requirements of the NSW State Parliament (Sendt 2002) have been addressed.

The 2010 Internal Audit Guidelines issued by the DLG outlined a range of accountability and governance requirements. These included recommendations that the internal audit function needed to be independent both in fact and in perception. The primary device to achieve this was through establishing an internal audit committee. The function of the internal audit committee in local councils is to support and oversee the direction of the internal audit activities, to provide independent oversight and separation from management and councillors. However, while these requirements were provided as mechanisms for ensuring good governance and accountability, they were only "strong recommendations" (DLG 2010b) and there was no capacity nor requirement of the DLG to enforce local councils to comply. Sterck and Bouckaert (2006) concluded in their study of audit trends in the public sector that regulatory mandated internal audit functions enhanced corporate governance. Prior research (Jones \& Bowrey 2013) showed that the level of compliance with the requirements to have an internal audit function, an independent audit committee and for 
the mayor of the council to be excluded from that committee was low. This research demonstrated that only one third of councils had an internal audit function. This indicated that non-mandated requirements for an audit committee are insufficient instruments to ensure that councils will comply.

The report of the NSW Independent Local Government Review Panel (Sansom et al. 2013) indicated that only about half of NSW had any kind of internal audit function and that they tended to focus on compliance, risk and fraud control, while many of those councils that do have internal audit functions are "strongly embedded within the councils and report directly to the general manager” (Sansom et al. 2013, p. 56). This diminishes the capacity of the internal audit function to work independently and can generate conflicts of interest. Reporting to the general manager rather than to an independent committee may create circumstances where the general manager may limit or conceal adverse internal audit reports. An analysis of the NSW local councils' Statements of Financial Performance for the 2012/13 financial year has shown that only 31 of 150 councils have recorded any expense in relation to internal auditing. The average amount recorded as an internal audit expense in 2013 was only $\$ 31,380$ and in 2012 was $\$ 30,710$, which is insufficient for one full time internal audit position. One reason for the low expenditure may be that councils contract out the internal audit function to external providers and limit the amount of work they conduct. However, this does suggest that many NSW Local Councils underfund the internal audit function and that there is a perception that the roles undertaken by internal auditor are non-essential.

The NSW Independent Local Government Review (Sansom et al. 2013, p. 56-57) has provided a number of recommendations to revitalise NSW Local Government. In relation to internal auditing these include requiring;

- $\quad$ Extending the concept of internal audit to include adding value and continuous improvement.

- $\quad$ All councils to have effective internal audit processes.

- Internal audit committees with a majority of independent members, an independent chair and preclude the general manager from membership.

- $\quad$ Requiring the chair of the internal audit committee to report at least biannually to a council meeting on financial management, good governance and continuous improvement.

- $\quad$ Empowering the Auditor-General to conduct issue-based performance audits in key areas.

Suggestions also include presentation and tabling of internal audit information at a public presentation such as the council meetings or annual meeting. All of these recommendations are aimed at providing higher levels of governance and accountability by local councils. 


\section{Conclusion}

NSW local councils have been provided with a range of recommendations to enhance and improve governance and accountability within the sector. These recommendations have been strongly recommended but have not been made compulsory and have lacked legislative authority to enforce compliance. Even when the DLG required the public release of financial reports (enforceable) (DLG 2009, DLG 2010a) this research has demonstrated that there was still not 100\% compliance. The NSW Independent Local Government Review (Sansom et al. 2013) suggests that it should be compulsory for local councils to have internal audits and independent audit committees. It appears clear that without legislative force local councils will continue to ignore the recommendations and fail to provide adequate levels of governance and accountability.

As trustees of public funds local councils have a responsibility to manage them prudently and protect the interests of the community. Safe guards such as an internal audit committee which is overseen by an audit committee, where the majority of members are independent and where the management of councils does not have a role, are essential for providing good governance and accountability. The current position is that many councils do not have an internal audit function at all and where they do have an internal audit function the majority of the internal auditors report to the general manager. This is problematic as there is no separation of roles and there is no capacity to report problems that may have derived from the general manager or that the general manager may wish to avoid scrutiny over. Therefore there is insufficient mechanisms for independent review and scrutiny. The recommendations from the NSW Independent Local Government Review (Sansom et al. 2013) will provide a framework for greater accountability and governance however they need to have legislative powers to enforce compliance. Clearly defined penalties for non-compliance is necessary as it is likely that Local Councils will need to be compelled to comply.

\section{References}

Allan, G. (2006). The HIH Collapse: A Costly Catalyst for Reform. Deakin Law Review 11(2): 137-160. Retrieved from file:///C:/Users/u1065630/Downloads/239-483-1SM.pdf

Australian National Audit Office. (2003a). Better Practice Guide: Framework, Processes and Practices. Public Sector Governance. Retrieved 21 Sept 2012 2012ttp://www.anao.gov.au/Publications/Better-Practice-Guides

Australian National Audit Office (2003b). Public Sector Governance Volume 1 - Better Practice Guide Framework, Processes and Practices. Retrieved 18 Aug 2012 http://www.anao.gov.au/ /media/Uploads/Documents/better_practice_public_sector_g overnance1.pdf

Australian Public Services Commission (2005). Foundations of Governance in the Australian Public Sector. Canberra, Commonwealth of Australia. Retrieved 12 Jan 2012 
http://www.apsc.gov.au/publications-and-media/archive/publicationsarchive/foundations-of-governance

Australian Public Services Commission (2007). Building Better Goverance. Canberra, Commonwealth of Australia. Retrieved 18 Oct 2012 http://www.apsc.gov.au/_data/assets/pdf_file/0010/7597/bettergovernance.pdf

Australian Securities and Investment Commission (2001). Corporations Regulations 9.2.03. Retrieved 21 Mar 2012 http://www5.austlii.edu.au/au/legis/cth/consol_reg/cr2001281/s9.2.03.html

Barrett, P. (2002). Achieving Better Practice Corporate Governance in the Public Sector. International Quality \& Productivity Centre Seminar, Australian National Audit Office. Retrieved from http://www.anao.gov.au/ /media/Uploads/Documents/achieving_better_practice_corpo rate_governance_in_the_public_sector1.pdf

Barton, A. (1999). Public and Private Sector Accounting - The Non-Identical twins. Australian Accounting Review 9(2): 22-31. Retrieved from http://onlinelibrary.wiley.com/doi/10.1111/j.1835-2561.1999.tb00105.x/pdf http://dx.doi.org/10.1111/j.1835-2561.1999.tb00105.x

Barton, A. (2005). Professional accounting standards and the public sector - a mismatch. Abacus- A Journal of Accounting Finance and Business Studies 41(2): 131-158. Retrieved from http://papers.ssrn.com/sol3/papers.cfm?abstract_id=731103 http://dx.doi.org/10.1111/j.1467-6281.2005.00173.x

Boon, K., S. Crowe, J. McKinnon, et al. (2005). Compulsory Audit Tendering and Audit fees: Evidence from Australian Local Government. International Journal of Auditing 9: 221-241. Retrieved from http://hdl.handle.net/1959.14/6415 http://dx.doi.org/10.1111/j.1099-1123.2005.00288.x

Bovens, M. (2007a). Analysing and Assessing Accountability: A Conceptual Framework. European Law Journal 13(4): 447-468. http://dx.doi.org/10.1111/j.1468$\underline{0386.2007 .00378 . x}$

Bovens, M. (2007b). Two Concepts of Accoutability: Accountabilty as a Virtue and as a Mechanism. West European Politics 33(5): 946-967. http://dx.doi.org/10.1111/j.1468-0386.2007.00378.x

Bowrey, G. (2008). Keeping up Appearances: The Quest for Governance Legitimacy. Accounting, Accountability \& Performance 14(1): 4-34. Retrieved from http://search.informit.com.au/documentSummary;dn=784963533722819;res=IELBUS

Broadbent, J. \& R. Laughlin (2003). Control and Legitimation in Government Accountability Processes: The Private Finance Initiative in the UK. Critical Perspectives on Accounting 14: 3-48. http://dx.doi.org/10.1006/cpac.2001.0525 
Brown, M. (2011). High Levels of Trust Make Local Government Most Corrupt: ICAC. Sydney Morning Herald. 28 Oct Sydney.

Burritt, R. L. \& S. Welch (1997). Accountability for environmental performance of the Australian Commonwealth public sector. Accounting, Auditing \& Accountability Journal 10: 532-561. http://dx.doi.org/10.1108/09513579710367494

Carnegie, G. D. (2005). Promoting Accountability in Municipalities. Australian Journal of Public Administration 64(3): 78-87. http://dx.doi.org/10.1111/j.1467$\underline{8500.2005 .00454 . \mathrm{x}}$

Carnegie, G. D. \& B. P. West (2005). Making Accounting Accountable in the Public Sector. Critical Perspectives on Accounting 16: 905-928. http://dx.doi.org/10.1016/j.cpa.2004.01.002

Chua, W. F. \& A. Sinclair (1994). Interests and the Profession-State Dynamic: Explaining the Emergence of the Australian Public Sector Accounting Standards Board. Journal of Buiness Finance \& Accounting 21(5): 669-705. http://dx.doi.org/10.1111/j.14685957.1994.tb00343.x

Constitution Act (1900) (Cwlth) retrieved from http://www.austlii.edu.au/au/legis/cth/consol_act/coaca430/

Corporations Act. (2001). (Cwlth) Retrieved from http://www.austlii.edu.au/au/legis/cth/consol_act/ca2001172/

Department of Local Government (NSW) (2006). NSW Department of Local Government; Investment Requirements for NSW Councils. Retrieved from http://www.dtpli.vic.gov.au/_data/assets/pdf_file/0007/225187/080624AssetInvestmentGuidelines.pdf

Department of Local Government (NSW) (2008). International Audit Trends in the Public Sector. Retrieved 02/02/2011, from http://www.dlg.nsw.gov.au/DLG/Documents/information/0864\%20Internal\%20Audit\%20Guidelines.pdf

Department of Local Government (NSW) (2009). NSW Government's Response to the Final Report and Recommendations of the Independent Inquiry into the Financial Sustainability of NSW Local Government. Retrieved from http://trove.nla.gov.au/work/36476888?selectedversion=NBD45002155

Department of Local Government (NSW) 2010a, Circular to Councillors: Councillors Guide. Retrieved 07 Sept 2011 http://ebookbrowse.com/the-municipal-councillors-guide-pdfd131810418 
Department of Local Government (NSW) (2010b). Internal Audit Guidelines. Retrieved 07 Sept 2011 https://www.olg.nsw.gov.au/sites/default/files/Internal-Audit-GuidelinesSeptember-2010.pdf

Edwards, M. (2002). Public Sector Governance - Future issues for Australia. Australian Journal of Public Administration 61(2): 51-61. http://dx.doi.org/10.1111/1467$\underline{8500.00272}$

Funnell, W. (1998). The Narrative and its Place in the New Accounting History: The Rise of the Counternarrative. Accounting, Auditing \& Accountability Journal 11(2): 142-162. http://dx.doi.org/10.1108/09513579810215446

Funnell, W. (2003). Enduring Fundamentals: Constitutional Accountaility and AuditorsGeneral in the Reluctant State. Critical Perspectives on Accounting 14: 107-132. http://dx.doi.org/10.1006/cpac.2002.0519

Funnell, W., R. Jupe \& J. Andrew (2009). In Government We Trust: Market Failure and the Delusions of Privatisation. Sydney, UNSW Press.

Gold, M. (2008). Financial Sustainability and the Imperative for Reform in Investment Organisation in Australia's Local Government Sector. Accounting. Accountability \& Performance 14(1): 35-56. Retrieved 20 Mar 2010 http://ro.uow.edu.au/gsbpapers/67

Gray, R. (2001). Thirty Years of Social Accounting, Reporting and Auditing: What (if anything) have we learnt? Business Ethics: A European Review 10(1): 9-15. http://dx.doi.org/10.1111/1467-8608.00207

Guthrie, J. (1998). Application of accrual accounting in the Australian public sector - rhetoric or reality? Financial Accountability and Management 14(1): 1-19. http://dx.doi.org/10.1111/1468-0408.00047

Hill, J. G. (2010). The Architecture of Corporate Governance in Australia. Retrieved 15/07/2011, 2011, from http://papers.ssrn.com/sol3/papers.cfm?abstract_id=1657810

Hood, C. \& G. Peters (2004). The Middle Aging of New Public Management: Into the Age of Paradox? Journal of Public Administration Research and Theory 14(3): 267-282. http://dx.doi.org/10.1093/jopart/muh019

Hoque, Z. (2004). Rationality, Accountability Reform and Accounting For Land Under Roads In An Australia Local Government. Journal of Public Budgeting, Accounting \& Financial Management 16(1): 1-18. Retrieved 20 April 2011 http://pracademics.com/attachments/article/502/Ar1\%20Hoque.pdf

Hoque, Z. (2005). Securing institutional legitimacy or organizational effectiveness? A case examining the impact of public sector reform initiatives in an Australian local authority. The International Journal of Public Sector Management 18(4/5): 267-382. http://dx.doi.org/10.1108/09513550510599274 
Jackson, A. \& I. Lapsley (2003). The Diffusion of Accounting Practices in the New “Managerial” Public Sector. International Journal of Public Sector Management 16(5): 359-372. http://dx.doi.org/10.1108/09513550310489304

Jones, G. \& G. Bowrey (2013). Local Council Governance and Audit Committees - The missing Link? Journal of New Business Ideas \& Trends 11(2): 58-66. Retrieved 10 Feb 2014 http://connection.ebscohost.com/c/articles/95525932/local-council-governanceaudit-committees-missing-link

Kent, J. (2003). The PSASB: the Accounting Profession in Regulatory Space. Australian Accounting Review 13(2): 10-15. http://dx.doi.org/10.1111/j.18352561.2003.tb00394.x

Kloot, L. (1999). Performance Measurement and Accountability in Victorian Local Government. The International Journal of Public Sector Management 12(7): 565-582. http://dx.doi.org/10.1108/09513559910308039

Mak, K., H. N. Deo \& K. A. Cooper (2005). Australia's Major Corporate Collapse: Health International Holdings (HIH) Insurance May The Force Be With You. Journal of the American Academy of Business 6(2): 104-112. Retrieved from http://www.jaabc.com/jaabcv6n2preview.html

Modell, S. (2005). Performance Management in The Public Sector: Past Experiences, Current Practices and Future Challenges. Australian Accounting Review 15(3): 56-66. http://dx.doi.org/10.1111/j.1835-2561.2005.tb00304.x

NSW Education (2002). History of Local Government Act, NSW Government, Department of Education. http://www.schools.nsw.edu.au/nswconstitution/html/6th/bgr/invest2.html Accessed 8 July 2013.

NSW Government. Parliament of New South Wales, History of Democracy. http://www.parliament.nsw.gov.au/prod/web/common.nsf/key/HistoryofDemocracyin NSW Accessed 20 August 2014.

Parker, L. D. (2005). Corporate Governance Crisis Down Under: Post-Enron Accounting Education and Research Inertia. European Accounting Review 14(2): 383-394. http://dx.doi.org/10.1080/09638180500126876

Sansom, G., J. Munro \& G. Inglis (2013). Revitalising Local Government- Final Report of the NSW Independent Local Government Review Panel: 1-136. Retrieved from http://www.localgovernmentreview.nsw.gov.au/Information.asp?areaindex=LGR\&ind $\mathrm{ex}=102 \& \mathrm{mi}=9$

Sendt, B. (2002). Governance and Accountability in the Public Sector. Keynote Address PNG Institute of Accountants Conference. 
Skalen, P. (2004). New Public Management Reform and the Construction of Organizational Identities. The International Journal of Public Sector Management 17(2/3): 251-263. http://dx.doi.org/10.1108/09513550410530171

Sterck, M. \& G. Bouckaert (2006). International Audit Trends in the Public Sector. The Internal Auditor 63(4): 49-54. Retrieved from http://connection.ebscohost.com/c/articles/21904242/international-audit-trends-publicsector

Stilwell, F. \& P. Troy (2000). Multilevel Governance and Urban Development in Australia. Urban Studies 37(5/6): 909-930. http://dx.doi.org/10.1080/00420980050011154

Trippett, J. \& R. Kluvers (2010). Accountability and Information in Local Government. World Journal of Management 2(3): 22-33. Retrieved from http://www.wjmpapers.com/previous_issue/October/2010

Trustees Act (1925). (NSW) Retrieved 11 Sept 2011 http://www5.austlii.edu.au/au/legis/nsw/consol_act/ta1925122/

Uhrig, J. (2003). Review of the Corporate Governance of Statutory Authorities and Office Holders. Canberra, Commonwealth of Australia. Retrieved from http://www.finance.gov.au/archive/financialframework/governance/review_corporate_governance.html

Warburton, J. \& G. Baker (2005). Integrity systems and Local Government. Australian Journal of Public Administration 64(2): 62-68. http://dx.doi.org/10.1111/j.1467-8500.2005.00441.x

Worthington, A. C. \& B. E. Dollery (2002). An Analysis of Recent Trends in Australian Local Government. The International Journal of Public Sector Management 15(6/7): 496-515. http://dx.doi.org/10.1108/09513550210439643 